\title{
Nano bio pesticide to constraint plant destructive pests
}

\begin{abstract}
Pest affects plants in nature worldwide, leading to excess use of mineral fertilizers and toxic pesticides, effecting environments, plants, animal and causes serious health problems to farmers. The indiscriminate use of bio pesticide has led pest resistance, reduce soil fertility and finally there is an emergence of novel product to intercept the pest situation. Nanoscience a new discipline have great deal of application in various fields and may also be useful in agrochemical and plant protection area to control pest to considerable extent. Until now, nanoparticles were used in formulation of nano based pesticides and insecticides, encapsulated nanoparticles, nanoparticle-mediated gene or DNA transfer in plants and bio sensors for remote sensing for precision farming. The nanopesticides of biological origin named as bio- nanopesticide could be fabricated using any metal such as $\mathrm{Ag}, \mathrm{Cu}, \mathrm{SiO}_{2}, \mathrm{ZnO}$ with broad-spectrum pest protection efficiency. However, extensive research and spectrum of various field studies are specially required to develop understanding of interaction between nanoparticles, microorganisms, soil, plants and humans. In present paper, a critical analysis is addressed in a problem of pest in field and usage of conventional solution and nano bio pesticides for applications in crop protection systems.
\end{abstract}

Volume 6 Issue 3 - 2017

\author{
Bipin D Lade,' Gogle DP,' Nandeshwar SB² \\ 'Department of Botany, RTM Nagpur University, India \\ ${ }^{2}$ Department of Biotechnology, Central Institute for Cotton \\ Research CICR, India
} Correspondence: Bipin D Lade, Department of Botany, RTM
Nagpur University, Nagpur 440033, Maharashtra, India; Email dbipinlade@gmail.com

Received: October II, 2017 | Published: October 26, 2017

Keywords: Silver nanoparticles, Pest management, Nano Biopesticides, Helicoverpa Armegera, Crop productivity

\section{Introduction}

Insects-pest is animal populations, which occurred in every possible environment with a varied number of species. The several insects are vectors of different diseases, and cause damages to crop plants. These have been affecting economy and the yield of crop plant and at national and international market. The crop yield losses caused by insects in agriculture, several chemicals have been applied to control them. ${ }^{1}$ Insect- pests are one of the leading causes that affect agriculture productivity resulting in billion dollars loss per annum . ${ }^{2}$ The two main forms i.e. larva and adult have been most lethal for most of the crop plants. For example, the deadly pest Helicoverpa armigera cause damage in the field and horticulture crops around the globe ${ }^{3}$ It has been major prevalence affecting in Asia, Europe, Africa, Oceania and South America . ${ }^{3}$ The major crop plants that are affected by Helicoverpa armigera are Chickpea, Corn, Cotton.$^{4}$ Peanut, Pigeon pea, Sorghum and Tomato. H. armigera has been effecting on over 180 cultivated hosts and 45 families of wild plant species . ${ }^{3}$ The cotton yield is low due to 150 different pest attack at various life stages . ${ }^{5}$ This has made an emergence for a researcher to compile the traditional and advance techniques to overcome various pest threats around the world.

The insect-host plant interaction leads to activation of plants immune system and there is cross talk between various pathways for production of both primary and secondary metabolites. The cell wall acts as barrier to insect however, becomes crossable for lethal insects leds to final destruction of plant. The secondary metabolites produced acts as specific defensive systems that are activated upon insect interaction. The phenylpropanoid pathway metabolites have extensive role for formation of various metabolites with definite characteristic. The plant secondary metabolites helps plant in several ways such as (i) prevention of herbivore and pathogen attack, attraction of pollinators and symbionts, and plant-plant communication . ${ }^{6}$ Thus secondary metabolites based biopecticides are the natural source that could be targeted to get rid of pest and are ecofriendly. These biopecticides are organic, low-risk, environmentally friendly as compare to the synthetic pesticides. Thus, the exploration of plants that having potential against insect pest is the chief for controlling their population and to save agriculture losses.

The plant such as weed plant that having no importance in agriculture could be dissects to identify many useful secondary metabolites that can be effective against pests. There are some plants with inherent capacity to deal pest, their extract shows different insect resistant compounds such as for example camphor, limonene and b-caryophyllene from Ocimum kilimandscharicum . ${ }^{7}$ The neem extract is pioneered for characteristic of larvicidal and pesticidals activity.${ }^{8}$ The weed plant Argimone maxicana.${ }^{9}$ Calotropis procera.${ }^{10}$ Dathura, Catharanthus roseus contents phytochemicals and secondary metabolites essential to minimize insect population. The need to formulate the biopesticide with efficient insect killing property is attempted by mixing different secondary metabolites in various ratios. However the constant use of the best sale biopesticide has put itself in danger for resistance in pest. It has allowed scientists and researchers all over the world to assemble the efficient secondary metabolites against insect-pest. The other alternative hidden in nature against pest needs to open up with the existing technologies. The greener method to avoid pollution and safer use with minimum toxicity for animals and plants is the best alternative. The Green chemistry topic that uses the green natural material as starting source to formulate the nano size particle capped with the pest resistant secondary metabolites could be possible solution to defect pest in farms.

In respect to above scenario, the current paper discusses the general demand for biopesticides, chemical, biological ways to dealt pest and the latest nano- biopesticides that can be formed using different plant extract complex with silver nano particles and their essays against pest- insect are communicated.

\section{Discussion}

There are many varied types of pesticides is used to treat effective against specific pests. The term "cide" comes from the Latin word 
"to kill . ${ }^{11}$ There are thousands of private pesticides manufacture, formulator and producer with some National companies in different countries. The Pesticide products are usually consists of active ingredients and other ingredients. The active ingredients is main entity that eliminates pest, in contrast, the other ingredients assist in several ways such as attracting the pest, spreading the active ingredients around, and/or reducing drift. ${ }^{11}$ The Pesticides are classified according to their targets as shown in Table 1. In current paper, the insecticides are the main concern that destroying thousands of plant species.

Table I Show classification of Pesticide according to their target

\begin{tabular}{lll}
\hline Sr no & Pesticide Type & Target Pest \\
\hline 1 & Nematicides & Nematodes (roundworms) \\
2 & Molluscicides & Slugs and snails \\
3 & Insecticides & Insects \\
4 & Acaricides (or miticides) & Fleas, ticks and mites \\
5 & Piscicides & Fish \\
6 & Avicides & Birds \\
7 & Rodenticides & Rodents \\
8 & Bactericides & Bacteria \\
9 & Algicides & Algae \\
10 & Fungicides & Fungi \\
II & Herbicides & Plants \\
\hline
\end{tabular}

\section{Global demand of biopesticides}

In the contemporary world the main focus is to design, formulate the ecofriendly pesticide that produced for a minimum amount to the investment with the efficiency of high potential. The eco-friendly bio pesticide's formulation and their demand as product consumption by farmers were elevated. The nations of a world put constant effort for development of efficient bio pesticides. It was observed that the global bio pesticide and synthetic pesticide market grew from $\$ 54.8$ to $\$ 61.8$ billion in 2013-2014 and estimated to expand to $\$ 83.7$ billion by $2019 .{ }^{12}$ Furthermore, the global sale for bio pesticide is estimated to reach a USD 6.9 billion by 2019. The scenario in Asia-Pacific region ergs for $20 \%$ demand for bio pesticides, however, the North America dominated by a requirement of $40 \%$ of market demand. There are many countries that rely on bio pesticides for pest managements in agricultural biotechnology to provide food security.$^{13}$ Thus the sale of bio pesticides has been increased as compared to chemical's pesticides.

Chemical-based pest management (traditional trend): The most common chemicals pesticides are available in local pest store, online source such as Amazon and there are several manufacture, dealer and exporter. In early days Sulphur element was used to make several chemicals products such as sulfuric acid, phosphate fertilizers, fungicides and insecticides. Apart from sulphure the general active chemicals ingredients are abamectin, cyfluthrin, fipronil, permethrin, bifenthrin, hydramethylnon, pyrethrum and boricacid. The chemical based pests are classified on basis of their chemical structure like organophosphates, carbamates, organochlorines, pyrethroids and neonicotinoids. Table 2 shows some of the important chemicals that used as insecticides with their effect on animal, insect, plant and humans. There are many insecticides available at the market some of them are acephate, azadirachtin, bioresmethrin, carbaryl, carbaryl, dichlorvos, fenitrothion, malathion, pirimiphos methyl, pyrethrum and quinalphos. The management of Pest has elevated the use of variety of chemical insecticide, pesticides and synthetic insecticide i.e. pyrethroids. The continuous exposure of synthetic pyrethorids has led the insect to escape through resistance.${ }^{14}$ Thus the traditional chemicals based pesticides are failed to manage a pest on crop plants. These have an emergence the use of alternative mode for plant protection i.e the use of biological plant derived natural compounds, phytochemicals and secondary metabolites. The chemicals based nanoparticles are synthesized and applied to evaluate their efficiency against larvae. The nanoparticles of novaluron, a water-insoluble insecticide was prepared which consists of nanoparticles sized $30-100 \mathrm{~nm}$ that shows toxicity in vivo experiments with Egyptian cotton leafworm Spodoptera littoralis larvae. However, the byproducts remains after experiments were hazardous chemicals thus the chemicals are not the choice for nanoparticles development in agriculture chemicals sector.$^{15}$.

Table 2 The chemical structure and effect on insects humans and other animals

\begin{tabular}{|c|c|c|c|}
\hline & Name of Chemicals & Effect & Activity \\
\hline I & Organophosphates & $\begin{array}{l}\text { Insect, humans and other } \\
\text { animals }\end{array}$ & $\begin{array}{l}\text { Kill insects by interfering with } \\
\text { brains and nervous systems. }\end{array}$ \\
\hline 2 & Carbamates & $\begin{array}{l}\text { They break down quicker, } \\
\text { less dangerous to humans }\end{array}$ & $\begin{array}{l}\text {, Kill insects by interfering with } \\
\text { s brains and nervous systems. }\end{array}$ \\
\hline 3 & $\begin{array}{l}\text { Organochlorines } \\
\text { Dichlorodiphenyl } \\
\text { trichloroethane }\end{array}$ & $\begin{array}{l}\text { Found in soil, in the } \\
\text { bodies of animals and } \\
\text { humans. Causing the } \\
\text { developing babies to die. }\end{array}$ & $\begin{array}{l}\text { Persistent pesticide, not } \\
\text { breakdown easily, disrupts } \\
\text { human endocrine systems, } \\
\text { damage genes and risk of cancer }\end{array}$ \\
\hline 4 & Pyrethroids & Less effect to human & $\begin{array}{l}\text { Feelings of numbness, itching, } \\
\text { burning, stinging, tingling. }\end{array}$ \\
\hline 5 & Neonicotinoids & $\begin{array}{l}\text { Neonicotinoids are } \\
\text { derived from nicotine, } \\
\text { a plant chemical, effects } \\
\text { many species \& mammals. }\end{array}$ & $\begin{array}{l}\text { Interfere with a pathway of } \\
\text { insect nervous system and role } \\
\text { in honeybee colony collapse } \\
\text { disorder }\end{array}$ \\
\hline
\end{tabular}

Biological-based pest management (old trend): The plant derived phytochemicals have been used as biopesticide with an advantage of non toxic to animals and human. The plants secondary metabolites such as alkaloids, terpenoids, flavonoids, phenol, polyphenons, glycosides and tannins have varied bioactivity against harmful insects. These secondary metabolites based bio pesticide has managed the pest Helicoverpa armigera to certain extent ${ }^{16}$ Some other common examples that are biological control are Anopheles subpictus, Bacillus thuringiensis, Bacillus thuringiensis serovar kurstaki, Beauveria bassiana and Culex quinquefasciatus. ${ }^{17}$ There are several research publications indicating the optimistic effect of medicinal plant extracts, powder, against pests such as Mosquito and Helicoverpa armigera etc. Large number of curative plants that have a characteristic of larvicidal and pesticidals activity such as neem extract.$^{8}$ Acorus calamus, Annona squamosa, Vitex negundo.$^{18}$ Gnidia glauca, Toddalia asiatica. ${ }^{19}$ and Argimone maxicana.$^{9}$ Calotropis procera.$^{10}$ The work of.$^{20}$ confirms the percent infestation reduction is highest in neem seed kernel extract $(30.08 \%)$ followed by tobacco leaf extract $(28.68 \%)$. The aqueous extract of neem seed kernel (NKAE) was tested in laboratory condition to evaluate its antifeedant, ovicidal, nymphl duration and hatching performance on tea mosquito bug (Helopeltis theivora).$^{21}$ The Table 3 displays some sources of botanical pesticides, active compound and their mode of action. The plant parts such as fruit stem, root, fruit and leaves have been molded into extract and their efficiency has been checked against insect-pest. The.$^{22}$ tested aqueous bark extract of Ficus racemosa was tested against fourth instar larvae of filariasis vector, Culex quinquefasciatus and Japanese encephalitis vectors, Culex gelidus. The bark extract of $F$. racemosa LC50 and r2 values were calculated and maximum efficacy against the larvae of Cx. quinquefasciatus and Cx. gelidus (LC50 $=67.72$ and $63.70 \mathrm{mg} / \mathrm{L}$; r2 $=0.995$ and 0.985 ). The use of plant parts extract is always an upper choice from ecological point of view. The extract contents various 
bioactive metabolites that possessed pesticidal property. Some of the sources of plant carrying pesticidal property along with their mode of action are given in Table 3. However, indiscriminate application of biological pesticide formed using parts of plants would come out with the resistance and there will be an emergence of novel product to tackle the pest situation. Thus another scientific alternative need to explore for minimizing Pest effect on crop plants.

Table 3 Some sources of botanical pesticides, active compound and their mode of action. The data have been retrieved from. ${ }^{23}$

\begin{tabular}{|c|c|c|c|c|}
\hline Sources & Bioactive compounds & Function & Mode of action & Properties \\
\hline $\begin{array}{l}\text { Seed and leaf } \\
\text { extracts of } \\
\text { Azadirachta } \\
\text { indica }\end{array}$ & Azadirachtin $\left(\mathrm{C}_{35} \mathrm{H}_{44} \mathrm{O}_{16}\right)$ & $\begin{array}{l}\text { Insecticide } \\
\& \text { fungicide }\end{array}$ & $\begin{array}{l}\text { Blocks the synthesis and release of } \\
\text { moulting hormones (ecdysone). } \\
\text { Disrupts the normal mating behaviour } \\
\text { and results in reduced fecundity. } \\
\text { Anti-feedant / repellent effect on many } \\
\text { insects. }\end{array}$ & $\begin{array}{l}\text { Photo-degradable } \\
\text { Half-life } 20 \mathrm{~h} \\
\text { Acute oral LD } \\
>5000 \mathrm{mg} \mathrm{kg}^{-1} \text { to rat is }\end{array}$ \\
\hline $\begin{array}{l}\text { Dried flowers of } \\
\text { Chrysanthemum } \\
\text { cinerariaefolihm }\end{array}$ & $\underset{\substack{x \rightarrow 0 \\
\text { hion }}}{\infty}$ & $\begin{array}{l}\text { Insecticide } \\
\& \text { acaricide }\end{array}$ & $\begin{array}{l}\text { Disrupts the sodium and potassium ion } \\
\text { exchange process in nerve axons. } \\
\text { Rapid knockdown effect on flying } \\
\text { insects. }\end{array}$ & $\begin{array}{l}\text { Photo-degradable } \\
\text { Acute oral LD } \mathrm{s}_{0} \text { to rat is } \\
350-2000 \mathrm{mg} \mathrm{kg}^{-1} \text { (depends } \\
\text { on purity) }\end{array}$ \\
\hline $\begin{array}{l}\text { Roots and } \\
\text { rhizome extracts } \\
\text { of Derris sp., } \\
\text { Lonchocarpus sp. } \\
\text { \& Tephrosia sp. }\end{array}$ & $\mathrm{ne}(\mathrm{C}-\mathrm{H}$ & $\begin{array}{l}\text { Insecticide, } \\
\text { acaricide \& } \\
\text { piscicide }\end{array}$ & $\begin{array}{l}\text { Inhibits ecllular respiration (at site I) } \\
\text { within electron transport chain and } \\
\text { prevents energy production. }\end{array}$ & $\begin{array}{l}\text { Highly toxic to fish } \\
\text { Acute oral } L D_{50} \text { to rat is } \\
132 \mathrm{mg} \mathrm{kg}^{-1}\end{array}$ \\
\hline $\begin{array}{l}\text { Stem extracts of } \\
\text { Ryania speciosa }\end{array}$ & Ryanodine $\left(\mathrm{C}_{25} \mathrm{H}_{35} \mathrm{NO}_{9}\right)$ & Insecticide & $\begin{array}{l}\text { Affects muscles by binding to the } \\
\text { calcium channels in the sarcoplasmic } \\
\text { reticulum. }\end{array}$ & $\begin{array}{l}\text { More effective on selected } \\
\text { species } \\
\text { Acute oral } \mathrm{LD}_{\text {so }} \text { to rat is } \\
1200 \mathrm{mg} \mathrm{kg}^{-1}\end{array}$ \\
\hline $\begin{array}{l}\text { Leaf extracts of } \\
\text { Nicotiana } \\
\text { tabacum }\end{array}$ & e $\left(\mathrm{C}_{10} \mathrm{H}_{14} \mathrm{~N}_{2}\right)$ & Insecticide & $\begin{array}{l}\text { Causes continuous uncontrolled nerve } \\
\text { firing by binding with acetylcholine } \\
\text { receptors at nerve synapses. } \\
\text { Act as fumigant against sucking pests }\end{array}$ & $\begin{array}{l}\text { More effective on selected } \\
\text { species } \\
\text { Acute oral } \mathrm{LD}_{\text {so }} \text { to rat is } 50 \\
\mathrm{mg} \mathrm{kg}^{-1} \\
\text { Dermal adsorption in } \\
\text { human }\end{array}$ \\
\hline $\begin{array}{l}\text { Essential oil of } \\
\text { Origanum } \\
\text { vulgare } \\
\text { Thymus sp., } \\
\text { Origanum } \\
\text { majorana, }\end{array}$ & Carvacrol $\left(\mathrm{C}_{10} \mathrm{H}_{14} \mathrm{O}\right)$ & Bactericide & $\begin{array}{l}\text { Disrupts cell membrane of bacteria, e.g. } \\
\text { Pseudomonas aeruginosa. } \\
\text { Inhibits the growth of several bacteria } \\
\text { strains, e.g. Escherichia coll and } \\
\text { Bacillis cereus }\end{array}$ & $\begin{array}{l}\text { In rats, carvacrol is } \\
\text { metabolized and excreted } \\
\text { within } 24 \mathrm{~h} \text {. }\end{array}$ \\
\hline $\begin{array}{l}\text { Fruit extracts of } \\
\text { Citrus sp. }\end{array}$ & Limonene $\left(\mathrm{C}_{10} \mathrm{H}_{16}\right)$ & Insecticide & Used as repellent & $\begin{array}{l}\text { Non-toxic to humans, birds } \\
\text { and animals }\end{array}$ \\
\hline $\begin{array}{l}\text { Bud and leaf } \\
\text { extracted essential } \\
\text { oils of Syzygizum } \\
\text { aromaticum. }\end{array}$ & Eugenol $\left(\mathrm{C}_{10} \mathrm{H}_{12} \mathrm{O}_{2}\right)$ & Insecticide & Used in bait to attract and collect insects & $\begin{array}{l}\text { Causes hepatotoxicity in } \\
\text { humans }\end{array}$ \\
\hline $\begin{array}{l}\text { Essential oil of } \\
\text { Eucalyptus } \\
\text { globulus }\end{array}$ & Eucalyptol $\left(\mathrm{C}_{10} \mathrm{H}_{18} \mathrm{O}\right)$ & Insecticide & $\begin{array}{l}\text { Used as repellent } \\
\text { Used in bait to attract and collect insects }\end{array}$ & $\begin{array}{l}\text { Acute oral LD } D_{50} \text { to rat is } \\
2480 \mathrm{mg} \mathrm{kg}^{-1}\end{array}$ \\
\hline
\end{tabular}


Nano-based pest management (new trend): Nanotechnology has been proposed to considerable extent and have been applied in numerous formulation to create many new products with a wide range of applications in several fields such as textile, geo sensing technology, paper, food, fertilizers, pesticides, plant protection, nutrition paint, food bio fuel, biomass, biocomposities and agrochemical industries .$^{24}$ Thus, nano based innovative nanopesticides such as $\mathrm{Ag}, \mathrm{Cu}$, $\mathrm{SiO}_{2}, \mathrm{ZnO}$ and nanoformulations show better broad-spectrum pest protection efficiency, reducing water, soils and environmental pollution in comparison with conventional pesticides.$^{25}$ The $\mathrm{Zn}$ is an essential nutrients for plants and is less available in soil this makes $\mathrm{Zn}$ metal as an important target for development of $\mathrm{Zn}$ nanoparticles for dealing with the pest and beneficial for plants. ZnO NP are of less cost and safe. They are applicable in various field such as anti- cancer, anti-diabetic, antibacterial,antifungal and agricultural properties, agrocemical industries. The other potential option could be silver. The silver (Ag) is used in the field of the biological system, living organisms, medicine, plant management, pest control and agricultural aspects with better efficiency and activity are the preferred target of the green method related to antibacterial, microbial, fungal, larvicidal, pesticidals, anti-inflammatory, antiplatelet activity, anti-angiogenesis and anti-viral activity ${ }^{8,25-27}$ The antifungal activity of $\mathrm{ZnO}$ nanoparticles against plant pathogen Fusarium graminearum have been demonstrated by.$^{28}$ The metal nanoparticles has an advantage of stability, slow kinetics which can be scale up for large quantity, performed at room temperature and generation of eco environmental byproducts.$^{29}$ Thus nanoformulation of bio pesticide could be the best possible alternative for development of pest-control weapons for harmful insect. Figure 1 shows the complete process of silver nanoparticles synthesis using Alo vera extract and $\mathrm{AgNO}_{3}$ under SUN conditions and its spray application to control insect-pest $H$. armegera. The synthesized bio nanoparticles (nanocorns shape) were mixed with water in definite quantity and filled in spray bottle, application on pest-insect $H$. armegera. Larvicidal activity of synthesized silver nanoparticles (AgNPs) using aqueous extract from Eclipta prostrata have been utilized to control the mosquito.$^{30}$ The fourth instar larvae of filariasis vector, Culex quinquefasciatus say and malaria vector, Anopheles subpictus Grassi (Diptera: Culicidae) were subjected to evaluation. The synthesized AgNP of 35-60nm in size shows he maximum efficacy in crude aqueous, and synthesized AgNPs against $C$. quinquefasciatus (LC50 $=27.49$ and $4.56 \mathrm{mg} / \mathrm{L}$; LC90 $=70.38$ and $13.14 \mathrm{mg} / \mathrm{L}$ ), and against $A$. subpictus (LC50 = 27.85 and $5.14 \mathrm{mg} / \mathrm{L} ; \mathrm{LC} 90=71.45$ and $25.68 \mathrm{mg} / \mathrm{L}$ ) respectively ${ }^{30}$ The work of ${ }^{31}$ shows that the leaves aqueous extracts of $E$. prostrata have the potential to be used as an ideal eco-friendly approach for the control of the S. oryzae. The LD50 values of aqueous extract, $\mathrm{AgNO}_{3}$ solution and synthesized $\mathrm{Ag}$ NPs were 213.32, 247.90, $44.69 \mathrm{mg} / \mathrm{kg}-1$; LD90=1648.08, 2675.13, $168.28 \mathrm{mg} / \mathrm{kg} \mathrm{-1}$, respectively. The Larvicidal efficacy of Catharanthus roseus Linn leaf extract have been positive Anopheles stephensi Liston.$^{32}$ The pest $\mathrm{H}$. armigera specific work of.$^{33}$ used leaf extracts of Peepal tree, Ficus religiosa (FR) and banyan tree, Ficus benghalensis (FB) for fabrication of AgNPs to modulate the function of gut protease activity in H. armigera. They confirmed bioassay of AgNPs with FR ( $50 \%$ concentration) and FB (70\% concentration) capable for reduction in larval weight and survival rate of $\mathrm{H}$. armigera. However the pure lavricidal compounds integrated with silver will always show better results than the mixture of secondary metabolites. This strategy needs to explore with reference to plant extract containing larvicidal activity.

\section{Possible nano bio-pesticides structures}

The plant protection is being the busiest area for researcher for the formulation of active solution to overcome the synthetic commercial pesticides. The traditional methods mixed with nanoscience with improved efficiency such as better solubility, slower releasing, and avoidance of prematurely degradation.$^{23}$ The biological compounds acts as capping and reducing agents to silver salt and formation of stabile nanoparticles takes place. Figure 2 shows the capping of repellent compound Aloin from Alo vera on formed silver nano particles. These nano biopsticides or nanomaterials could be used as a pesticide directly or indirectly as vector to inherent important characters such as stiffness, permeability, crystallinity, thermalstability, and biodegradability. These properties are advantageous over chemical or commonly used pesticides. The nanocarrier materials with definite pesticides secondary metabolites can cause indigestion in insects. They can break down the water protection barrier, resulting in desiccation and death of insect. The nano size helps to act efficiently to insect with minimum amount of nano bio-pesticides. The nano material also helps to protect the active secondary metabolites and assist in controlled release of bioactive compound to act on insect ${ }^{23}$ These are the possible ways in which nano bio-pesticides can be formed using plant pesticidal secondary metabolites and application of it in form of spray will ultimately help in pest removal and resistance. Figure 3 shows the possible nanostructure used for formulation of nano biopesticides using plant secondary metabolites.

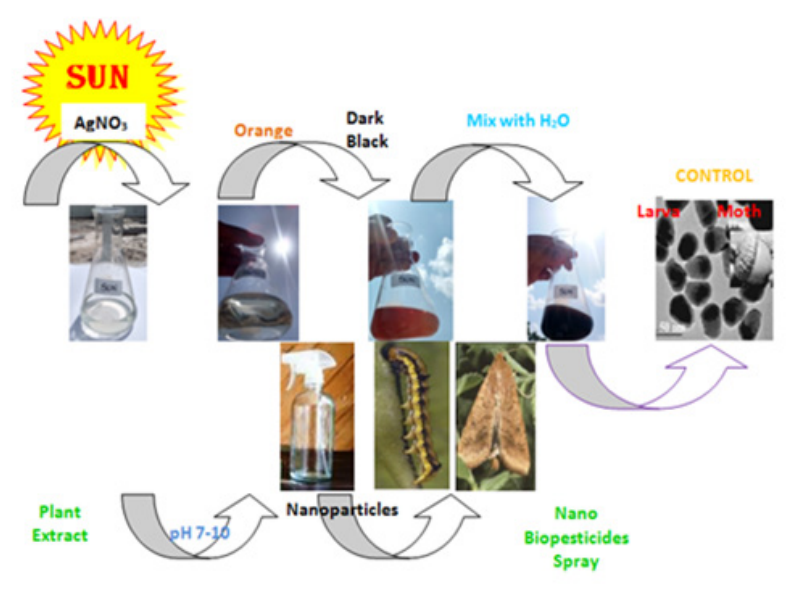

Figure I The complete process of silver nanoparticles synthesis using plant extract and $\mathrm{AgNO}_{3}$ under SUN conditions, From left to right; The leaf extract (Aloe vera) green color used for reduction of silver salt $\mathrm{AgNO}_{3}$, the desired $\mathrm{pH}$ of mixture is adjusted to 7-10, the nanocorn nanopartciles applied in form of spray to pest-insect, picture was taken from.$^{26}$

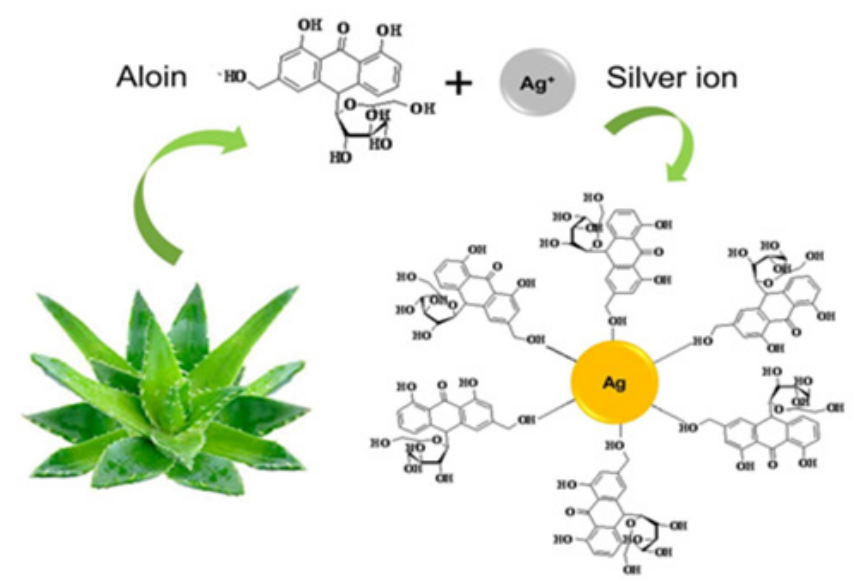

Figure $\mathbf{2}$ The capping of repellent compound Aloin from Alo vera on formed silver nano particles. This image retrieved from. ${ }^{34}$ 


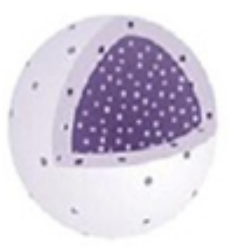

Nanocapsule

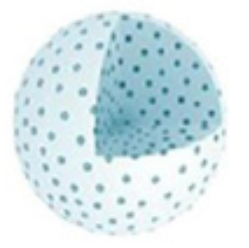

Nanosphere

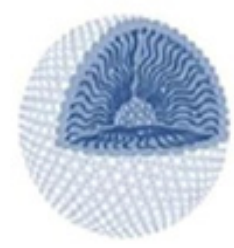

Micelle

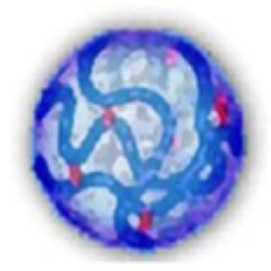

Nanogel

Figure 3 The possible nanostructure used for formulation of nano bio-pesticides, Pictures retrieved from. ${ }^{23}$

\section{Required qualify for selection as nano bio-pesticides}

In order to be safe, easy to prepare, low cost and effective pesticides to diminished the plant pest, the important points that needs to be consider are first, it must be easy for preparation, it must be effective at economic rates, could be targated against specific pest, may be effective against a wide variety of insect pests, it must be safer to all living beings and environments, it must be non toxic to farmers, it must not content any harmful subustance, must be approved by health authorities, must not get accumulate in food chain, it must not give rise to unacceptable residues, legal lethal dose concentration must be framed, it must not effect the quality of food, flavor, fragrances and texture, It must be acceptable in international market, it must not be flammable, explosive or corrosive, it must be easily applicable.

\section{Need of research}

Although there have been numerous studies of the toxicity effects of nanoparticles on bacteria, fungi, and animal pathogens. Little research has been carried out to investigate the toxicity effect of nanoparticles on insect's pest such as Amsacta moorei Butle, Episomus lacerta F, Brachytrypes portentosus Licht, Chrotogonus sp, Gryllulus domesticus Linn, Helicoverpa armigera, Laphygma exigua kb, Myllocerus maculosus Desbr, Pempheres affinis Fst Platyedra gossypiella Saund,Ragmus morosus Ball, Termites, Zeuzera coffeae Nietn. ${ }^{35}$ The extensive funding and direction in this area could be targeted to come up with the great findings for plant protection. The plant species containing secondary metabolites that are insect repellents must be identified and complexes with silver or other nano particles. These biologically synthesized nanoparticles effect on different pest- insect needs to clarify. This will conclude the plant species specific resistance for particular insect.

\section{Critical points for nano-biopesticides}

There is a great concern regarding the nano bio pesticides material, which has been potential to exert hazardous effects on soil, human and environment. The positive effect of nano-pesticide may have some negative effects, which need to be resolved by critical research. The interaction of nano based pesticides with soil, and chemical interaction's soil organic matter are other important aspects. Apart from nanoparticles the prime importance to acknowledge the particular plant species carrying peculiar photochemical may play a crucial role for nanoparticles formations. The plant inherited with pesticide phytochemical and secondary metabolites influences the future formed nanoparticles. There are some plants extract that have been exploited for insecticidals activity such as Catharanthus roseus L, Datura metal L, Cardiospermum halicacabum L, Argemone mexicana L, Calotropis procera L, Azadirachta indica L, Oscimum species wild, Oscimum sanctum L, Oscimum canum L and Citrus sinensis $\mathrm{L}$.

\section{In-vitro bioassay for Nano-biopesticides against pest control}

The lab based assays are important for potential determination of synthesized silver nanoparticles, which is called as an in-vitro assay. The possible foremost target for evaluation of synthesized SNP could be the food the pest prefers, the life stages of pest such as larvae, pupa and adult moth. Thus the antifeedant, larvicidal and cytotoxic activities of synthesized Nano-biopesticide fabricated from aqueous leaf extract of plants were of principal concern. The insect may be collected from any standard Indian Council of Agriculture Research (ICAR) Institute and instar larva could be maintained in lab. The antifeedent, pupicidal, insecticidal acticity can be tested for establishment of potential nano based product for agriculture plant protection.

Antifeedent activity: The plant extracts possessing antifeedant and insecticidals activities against several insect-pests has been demonstrated. The SNP synthesized using leaf aqueous extract of Manilkara zapota shows feeding deterrent activity against Musca domestica ${ }^{36}$ The leaf disc no choice method is usually employed ${ }^{37}$ In this, a fresh leaf disc of around $4 \mathrm{~cm}$ in diameter is dipped in varied concentrations of synthesized SNP extracts. The water can be taken as negative control and the leaf extracts as positive control. The petri dish is covered with hydrated filter paper, and one third instar larva may introduce into each petri dish. The consumption of leaf area by the treated and control larvae after $24 \mathrm{~h}$ was recorded using leaf area meter. The Leaf area, eaten by larvae in treatment was corrected from the negative control. The antifeedant activity could be measured using the formula given in Figure 4. The potential antifeedant (92.40 $\%$ ) activities against $\mathrm{H}$. armigera with LC50 values of 365.72 was recorded by.$^{38}$

$$
\text { Antifeedant activity }=\frac{\text { Leaf area consumed in control }- \text { treated leaf }}{\text { Leaf area consumed in control }+ \text { treated leaf }}
$$

Figure 4 Formula for measurement for antifeedant activity.

Larvicidal and pupicidal activity: The Larvicidal activity can be studied using leaf dip method ${ }^{39}$ Here the leaf discs of host plant dipped in different concentrations of water extract, synthesized SNP and Leaf extract. The activity is recorded after $24 \mathrm{~h}$ of treatment with continuous supply of fresh leaves for healthy growth. The larval mortality rate could be recorded after 96 hours of treatment ${ }^{40}$ The larvicidal $(100 \%)$ activities against $\mathrm{H}$. armigera with LC50 value $309.98 \mathrm{mg} / \mathrm{mL}$ was recorded by.$^{38}$ The percentage of larval mortality was calculated and corrected by Abbott's formula given in Figure $5 .{ }^{41,42}$ The mortality of Pest, larvae, pupal can be calculated and effectiveness of particular nanoparticles synthesized using plant extract may be determined. The large number of plant species could be pooled for evaluation of their antipesticidal activity. The in lab experiment for treatment of (1) control, CdS (2), Nano-Ag (3) and (4) Nano-TiO2 of effected larvae of S. litura due to is shown in Figure 6. 
Corrected Mortality $(\%) \equiv \%$ larval mortality in treatment $-\%$ larval mortality in control $\times 100$ 100 - \% larval mortality in control

Figure $\mathbf{5}$ The corrected mortality formula given by Abbott to determine percentage of larval mortality.

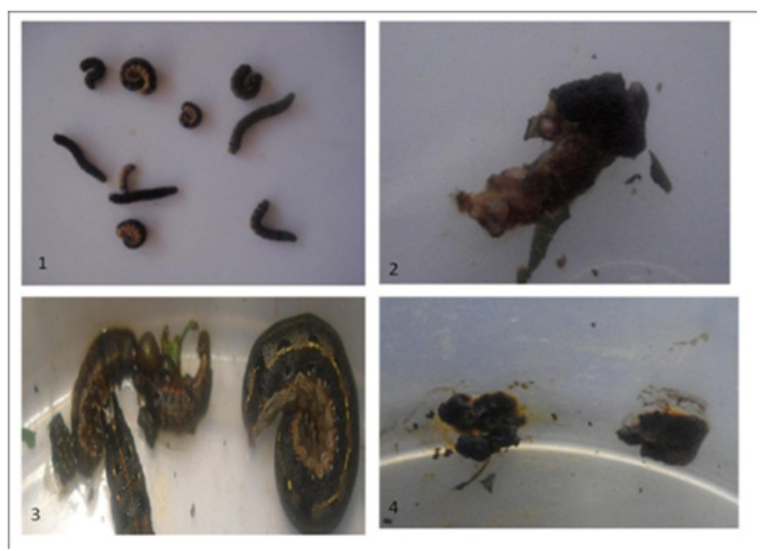

Figure 6 The effected larvae of S. litura after the treatment of (I) control, $\mathrm{CdS}(2), \mathrm{Nano}-\mathrm{Ag}(3)$ and (4) $\mathrm{Nano}^{-\mathrm{TiO}_{2}}$ is shown and the picture have been taken from ${ }^{42}$

Field test for nano-biopesticides for pest control: The nanobiopesticide mixed, in particular, quantity of water and sprayed in known quantity in a field of specific selected crop species to study the effect on plants comparing with the standard. The field spraying of nano-biopesticide will need appropriate handling and measurement of nano- biopesticides. The initial quantity of nano pesticide needs to optimized and mixed with water or selected non toxic solvent and sprayed in field. The spraying could be done manually by farmer, automated motors, some time using planes and helicopter based on size of farm. The Figure 7 shows the possible spraying techniques applicable in farms. The overall cost for formulation of silver nitrate, plant collection, extract preparation and lab facilities is very crucial, as it will decide the final cost of nano bio-pesticide formulation. The final comparison of cost for biopesticide and nano bio-pesticide will decide the future of nanobased pesticides. However, the test for their potential is critical aspect for nanotechnologist to established plant protection via nano bio-pesticide. This will conclude the effect of synthesized nano based bio pesticide and it's potential to use as NanoBio pesticides as a modern trend.
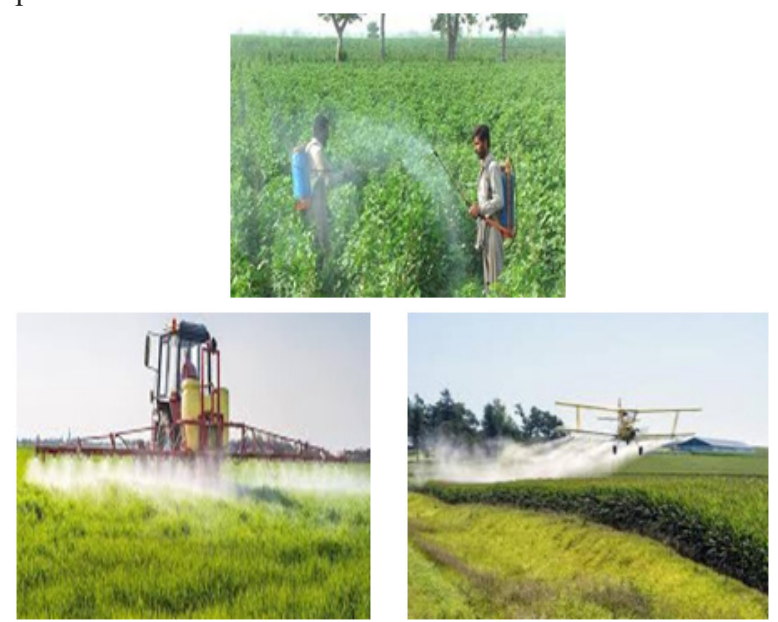

Figure 7 Shows the possible spraying techniques applicable in farms A: spraying by human manually, B: through spraying machine and $C$ : using planes in large farm.

\section{Conclusion}

The present articles deals with present pest-control traditional options and discusses the future approach of nano-biopesticides. The problem of pest is not restricted to geographical locations, and the current control measures are very toxic to ecology and human health. The vital challenges faced by pest control are the choice and availability of safe, effective and cheap bio insecticides is need of the day. Furthermore, magnetic nanoparticles could be an alternative for insect repellents with magnetic property helpful in geo-sensing technology. The plant with prominent insecticidals activity could be complexes with Zinc or silver and their efficacy my elevated to control several pests. This will also assist to minimize the most dangerous chemicals used as insecticides today in a field to pests.

\section{Acknowledgements}

I thanks to Professor \& Head Dr. Tadikamalla Srinivasu FBS Department of Botany, RTM Nagpur University for providing research facility and to permit me to carry out research work at Department of Botany, RTM Nagpur University, Nagpur 440033, Maharashtra, India, I would like to thanks to Professor \& Head Dr. M.K. Rai Department of Biotechnology, SGBA University, Maharashtra, India who introduce the flourishing nanoscience $\&$ nanotechnology subject.

\section{Conflicts of Interest}

The authors declare that they have no conflict of interests; BDL, DPG, SBN idea, designed, plan and wrote the manuscript. The DPG \& SBN suggestion and improvement of manuscript. BDL, DPG, SBN discussion, rechecked, revised and finalized manuscript. All authors read and approved the final manuscript.

\section{References}

1. Ragaei M, Sabry AH Nanotechnology for insect pest control. International Journal of Science, Environment and Technology. 2014;3(2):528-545.

2. Ramya S, Rajasekaran C, Sundararajan G et al. Antifeedant Activity of leaf aqueous extracts of selected medicinla plants on VI instar larva of Helicoverpa armigera, Ethnobotanical Leaflets. 2008;12:938-943.

3. Sullivan M, Molet T CPHST Pest Datasheet for Helicoverpa armigera. USDA-APHIS-PPQ-CPHST. 2007

4. Malik MF, Khan AG, Hussiany SW et al. Scouting and control of Helicoverpa armigera by synthetic pheromones technology in apple, Asian Journal of Plant Sciences. 2002;3:663-664.

5. Gandhi VP, Nimboodiri NV Economic of BT cotton verses non BT cotton in India, A study across for major cotton growing states Centre for management in agriculture Indian Institute of Management, Ahmedabad, India, pp. 2009;1-127.

6. Singh K, Panghal M, Kadyan S et al. Green silver nanoparticles of Phyllanthus amarus: as an antibacterial agent against multi drug resistant clinical isolates of Pseudomonas aeruginosa. Journal of Nanobiotechnology. 2014;12:1-40.

7. Singh P, Jayaramaiah RH, Sarate P et al. Insecticidal Potential of Defense Metabolites from Ocimum kilimandscharicum against Helicoverpa armigera, PLoS ONE. 2014;9(8):e104377.

8. Chopra RN, Badhwar R, Ghosh S Poisonous Plants of India, Indian Council of Agricultural Research, New Delhi, India. 1994

9. Malarvannan S, Senthil KS, Prabavathy VR et al. Individual and synergistic effect of leaf powder of few medicinal plants against American Bollworm, Helicoverpa armigera (Hubner) (Noctuidae: Lepidoptera). Asian Journal of Experimental Science. 2008;22(1):79-88. 
10. Lall D, Summerwar S, Pandey J Bioefficacy of plant extract against larvae of American Bollworm Helicoverpa armigera (Noctuidae: Lepidoptera) special reference to the effect on Peritrophic membrane. CCEE, $p$ 2014;21-23.

11. Naional Pest Information Center, Oregon State University and the US Ennvironmental Protection Agency, USA.

12. Lehr P BCC Research Global Markets for Bio pesticides, Market Research Reports. Code-CHM029E. 2014

13. Patent mall SDN BHD, Kuala Lumpur, Malaysia.

14. Kamaraj C, Abdul Rahuman A, Bagavan A Screening for antifeedant and larvicidal activity of plant extract against Helicoverpa armigera (Hubner), Sylepta derogata (F) and Anopheles stephensi (Liston). Parasitol Res. 2008;103(6):1361-1368.

15. Elek N, Hoffman R, Ravi U et al Novaluron nanoparticles: Formation and potential use in controlling agricultural insect pests. Colloids and Surfaces A: Physicochemical and Engineering Aspects. 2010;372:66-72.

16. Ge F, Ding Y The population energy dynamics of predacious natural enemies and their pest control activity in different cotton agroecosystems. Acta Entomologica. 1996;39(3):266-273.

17. Tamil Nadu agriculture University Coimbatore, extension initiative of TNAU. TNAU agritech portal, India.

18. Murugan K, Sivaramakrishnan S, Senthilkumar N et al. Synergistic interaction of botanicals and Biocides Nuclear polyhedrosis virus on pest control. Journal of Scientific and Industrial Research. 1998;57:732-739.

19. Sundararajan G, Kumuthakalavalli R Antifeedant activity of aqueous extract of Gnidia glauca Gilg. and Toddalia asiatica Lam. on gram pod borer, Helicoverpa armigera (Hbn). Journal of Environmental Biology. 2001;22(1):11-14.

20. Rahman AKMZ, Haque MH, Alam SN et al. Efficacy of Botanicals against Helicoverpa armigera (Hubner) in Tomato. The Agriculturists. 2014;12(1):131-139.

21. Dutta P, Reddy SGE, Borthakur BK Effect of neem kernal aqueous extract (NKAE) in Tea Mosquito Bug, Helopeltis theivora (Waterhouse, 1886) (Heteroptera: Miridae). Munis Entomology \& Zoology. 2013;8(1):213-218.

22. Velayutham K, Rahuman AA, Rajakumar G et al. Larvicidal activity of green synthesized silver nanoparticles using bark aqueous extract of Ficus racemosa against Culex quinquefasciatus and Culex gelidus. Asian Pac J Trop Med. 2013;6(2):95-101.

23. Nuruzzaman M, Rahman MM, Liu Y et al. Nanoencapsulation, Nanoguard for Pesticides: A New Window for Safe Application. Journal of Agricultural and Food Chemistry. 2016;64:1447-1483.

24. Sadowski Z Biosynthesis and applications of silver and gold nanoparticles. David Pozo Perez (Ed.), Silver Nanoparticles, pp. 2010;257-276.

25. Chhipa $H$ Nanofertilizers and nanopesticides for agriculture. Environ Chem Lett. 2017;15(1):15-22.

26. Kharissova OV, Kharisov BI, Garcia TM et al. A Review on Lesscommon Nanostructures. Synthesis and Reactivity in Inorganic, MetalOrganic, and Nano-Metal Chemistry. 2009;39(10):662-684.

27. Gao Y, Huang Q, Su Q, Liu R Green synthesis of silver nanoparticles at room temperature using Kiwifruit juice. Spectroscopic Letter 2014;47(10):790-795.
28. Dimkpa CO, Mc Lean JE, Britt DW, Anderson AJ Antifungal activity of $\mathrm{ZnO}$ nanoparticles and their interactive effect with a biocontro bacterium on growth antagonism of the plant pathogen Fusarium graminearum. Biometals. 2013;26(6):913-924.

29. Iravani S Green synthesis of metal nanoparticles using plants. Green Chem. 2011;13:2638-2650.

30. Rajakumar G, Rahuman AA Larvicidal activity of synthesized silver nanoparticles using Eclipta prostrata leaf extract against filariasis and malaria vectors. Acta Tropica. 2011;118(3):196-203.

31. Zahir AA, Bagavan A, Kamaraj C et al. Efficacy of plant-mediated synthesized silver nanoparticles against Sitophilus oryzae. Journal of Biopest. 2012;5(Supp):95-102.

32. Panneerselvam C, Murugan K, Kovendan K et al. Larvicidal efficacy of Catharanthus roseus Linn. (Family: Apocynaceae) leaf extract and bacterial insecticide Bacillus thuringiensis against Anopheles stephensi Liston. Asian Pacific Journal of Tropical Medicine. 2013;6(11):847-853.

33. Kantrao S, Ravindra MA, Akbar SMD, Jayanthi PDK, Venkataraman A Effect of biosynthesized Silver nanoparticles on growth and development of Helicoverpa armigera (Lepidoptera: Noctuidae): Interaction with midgut protease. Journal of Asia Pacific Entomology 2017;20(2):583-589.

34. Logaranjan K, Raiza AJ, Subash CB et al. Shape- and Size-Controlled Synthesis of Silver Nanoparticles Using Aloe vera Plant Extract and Their Antimicrobial Activity. Nanoscale Research Letter. 2016;11:520.

35. Devi DG, Murugan K, Selvam PC Green synthesis of silver nanoparticles using Euphorbia hirta (Euphorbiaceae) leaf extract against crop pest of cotton bollworm, Helicoverpa armegera (Lepidoptera: Noctuidae). J Biopest. 2014;7(Supp):54-66.

36. Kamaraj C, Rajakumar G, Rahuman AA et al. Feeding deterrent activity of synthesized silver nanoparticles using Manilkara zapota leaf extract against the house fly, Musca domestica (Diptera: Muscidae). Parasitol Res. 2012;111(6):2439-2448.

37. Isman MB, Koul O, Lucyzynski A, Kaminski J Insecticidal and antifeedant bioactivities of neem oils and their relationship to Azadirachtin content, Journal of Agricultural and Food Chemistry. 1990;38(6):1407-1411.

38. Siva C, Kumar MS Pesticidal activity of eco-friendly synthesized silver nanoparticles using Aristolochia indica extract against Helicoverpa armigera Hubner (Lepidoptera: Noctuidae). Inter J Adv Sci Tech Res. 2015;5(2):197-226.

39. Baskar K, Maheswaran R, Kingsley S, Ignacimuthu S Bioefficacy of Couroupita guianensis (Aubl) against Helicoverpa armigera (Hub) (Lepidoptera: Noctuidae) larvae. Spanish Journal of Agricultural Research. 2010;8(1):135-141.

40. Rogers JV, Parkinson CV, Choi YW et al. A preliminary assessment of silver nanoparticle inhibition of monkeypox virus plaque formation. Nanoscale Research Letter. 2008;3(4):129-133.

41. Jeyasankar A, Premalatha S, Elumalai K Antifeedant and insecticidal activities of selected plant extracts against Epilachna beetle, Henosepilachna vigintioctopunctata (Coleoptera: Coccinellidae). Advance Entomology. 2014;2(1):14-19.

42. Chakravarthy AK, Chandrashekharaiah, Kandakoor SB et al. Bio efficacy of inorganic nanoparticles CdS, Nano-Ag and Nano-TiO2 against Spodopteralitura (Fabricius) (Lepidoptera: Noctuidae). Current Biotica. 2012;6(3):271-281. 